\title{
ANALISIS FAKTOR-FAKTOR YANG MEMPENGARUHI MOTIVASI PEREMPUAN BERWIRAUSAHA ONLINE
}

\section{(ANALYSIS OF THE FACTORS THAT INFLUENCE THE MOTIVATION OF WOMEN ENTREPRENEURIAL ONLINE)}

\author{
Oleh: \\ Yuridistya Primadhita'), Anggraita Primatami'), Susilowati Budiningsih²) \\ Sekolah Tinggi Ilmu Ekonomi IPWI Jakarta1,2,3) \\ yuridistya_dhita@yahoo.com ${ }^{1)}$; anggraitami@gmail.com ${ }^{2}$; susilowatisubud@gmail.com ${ }^{3)}$
}

Submit: 27 Jun 2019 Review: 02 \& 03 Aug 2019 Accept: 03 Aug 2019 Publish: 18 Aug 2019

\begin{abstract}
This research aims to determine the factors that influence the motivation of women entrepreneurial online in Jakarta. These factors include family environment, capital, and freedom of work. The data used is the primary data of the questionnaire to 80 women respondents spread over the Jakarta area. The results showed that the family environment, capital, and freedom of work influenced women's motivation for online entrepreneurship. The family environment is positively influence the motivation of women entrepreneurial online, capital is positively influence the motivation of women entrepreneurial online, and the freedom of work is positively influence the motivation of women entrepreneurial Online.
\end{abstract}

Keywords:

Family environment, capital, freedom of work, motivation, online entrepreneurship

\section{ABSTRAK}

Penelitian ini bertujuan untuk mengetahui faktor-faktor yang mempengaruhi motivasi perempuan berwirausaha online di Jakarta. Faktor tersebut meliputi lingkungan keluarga, modal, dan kebebasan bekerja. Data yang digunakan merupakan data primer berupa kuisioner kepada 80 responden perempuan yang tersebar di wilayah Jakarta. Hasil penelitian menunjukan bahwa lingkungan keluarga, modal, dan kebebasan bekerja berpengaruh terhadap motivasi perempuan untuk berwirausaha online. Lingkungan keluarga berpengaruh positif terhadap motivasi perempuan berwirausaha online, modal berpengaruh positif terhadap motivasi perempuan berwirausaha online, dan kebebasan bekerja berpengaruh positif terhadap motivasi perempuan berwirausaha online.

Kata kunci:

Lingkungan keluarga, modal, kebebasan bekerja, motivasi, wirausaha online 


\section{PENDAHULUAN}

Perempuan memiliki potensi yang sangat besar untuk ikut berpartisipasi dan memberikan manfaat bagi perekonomian dan pembangunan negara. Perempuan yang bekerja dan aktif berpartisipasi dalam kegiatan ekonomi merupakan hal umum yang seringkali ditemui saat ini. Posisiposisi penting di masyarakat tidak jarang diemban oleh perempuan. Banyak prestasi yang membanggakan yang berhasil didapat oleh kaum perempuan di ranah publik. Peran perempuan semakin hari semakin berkembang di masyarakat dalam mendukung keberhasilan pembangunan. Bertambahnya kesadaran akan pentingnya peran perempuan di masyarakat menjadikan isu kesetaraan gender menjadi poin kelima yang harus diwujudkan dari tujuh belas program Sustainable Development Goals (SDGs) yang diputuskan oleh Perserikatan BangsaBangsa (UNDP, 2018:10).

Dalam era persaingan global yang semakin masif saat ini, keaktifan perempuan di dalam perekonomian juga semakin meningkat. Salah satunya, tercermin pada semakin bertambahnya wirausaha perempuan terutama di sektor usaha mikro kecil menengah (UMKM). Berkembangnya wirausaha perempuan di sektor UMKM dapat berpengaruh terhadap meningkatnya kemandirian ekonomi keluarga dan pada akhirnya berdampak pada pengentasan kemiskinan. Data Bank Dunia tahun 2016 menunjukkan rasio kepemilikan usaha yang dikelola oleh perempuan di Indonesia lebih tinggi dibandingkan dengan rasio dunia, terutama yang terjadi pada sektor UMKM. Bank Indonesia mencatat total UMKM di tahun 2018 mencapai 57,83 juta dengan lebih dari $60 \%$ usaha dikelola oleh perempuan, dimana jumlah pelaku UMKM perempuan di Indonesia mencapai 37 juta. Tercatat, bidang UMKM yang paling banyak dikelola perempuan adalah bidang kuliner yaitu sebesar $41,69 \%$.

Alasan perempuan berwirausaha dapat muncul dari berbagai motif. Penelitian-penelitian yang berfokus pada wirausaha perempuan menemukan bahwa terdapat faktor internal dan faktor eksternal yang dapat mempengaruhi minat perempuan berwirausaha. Penelitian Primadhita, dkk (2018:169) menemukan bahwa faktor internal dan faktor eksternal berpengaruh signifikan terhadap keputusan perempuan berwirausaha. Faktor internal tersebut meliputi keyakinan diri, keahlian, dan motivasi diri. Sementara, faktor eksternal meliputi lingkungan keluarga, lingkungan sosial, dan risiko. Pada penelitian tersebut, faktor eksternal memiliki pengaruh yang lebih besar dibandingkan dengan faktor internal. Penelitian Munfaqiroh (2018:38) menemukan faktor modal, kemandirian, dan faktor keluarga berpengaruh signifikan terhadap keputusan perempuan berwirausaha, dimana faktor modal memiliki pengaruh yang paling dominan. Pada prakteknya, UNDP (2018:14) mencatat bahwa dalam hal modal yang berasal dari pembiayaan, masih terdapat kesenjangan antara akses pasar dengan kebutuhan modal di kalangan wirausaha perempuan di Indonesia.

Ketika perempuan memutuskan untuk berwirausaha, ia akan menghadapi peran ganda yang meliputi peran di ranah domestik sebagai pengurus keluarga dan peran di ranah publik sebagai pelaku usaha. Agar kedua peran tersebut dapat berjalan saling beriringan, solusi yang dapat dilakukan salah satunya adalah dengan memiliki usaha rumahan. Dengan usaha rumahan, perempuan dapat memulai dan mengembangkan usaha tanpa harus meninggalkan keluarga. Perkembangan era digitalisasi saat ini dinilai cukup memudahkan usaha 
rumahan untuk berkembang. Perkembangan bisnis online yang mulai menjamur membuat wirausaha perempuan semakin mudah dalam menjalankan usahanya di rumah atau di tempat yang berlokasi tidak jauh rumah. Penelitian Firman (2018:280) menemukan bahwa keberhasilan diri, toleransi risiko, dan kebebasan bekerja berpengaruh signifikan terhadap keinginan perempuan berwirausaha online.

\section{TUJUAN PENELITIAN}

Penelitian ini dilakukan dengan tujuan sebagai berikut:

1. Mengetahui apakah lingkungan keluarga memiliki pengaruh terhadap motivasi perempuan berwirausaha online di Jakarta.

2. Mengetahui apakah modal memiliki pengaruh terhadap motivasi perempuan berwirausaha online di Jakarta.

3. Mengetahui apakah kebebasan bekerja memiliki pengaruh terhadap motivasi perempuan berwirausaha online di Jakarta.

\section{TELAAH LITERATUR DAN PENGEMBANGAN HIPOTESIS Wirausaha Perempuan}

Menurut Pambudy (2017:6), wirausaha adalah pengambil risiko dan inovator yang menghasilkan produk berupa barang dan jasa yang dapat meningkatkan lapangan kerja dan pertumbuhan ekonomi. Sementara Barani dan Dheepa (2013:25) dalam Primadhita dkk (2018:162) menyatakan wirausaha perempuan dapat didefinisikan sebagai wanita atau sekelompok wanita yang memulai, mengatur dan mengoperasikan perusahaan bisnis, baik dalam skala kecil atau rumahan maupun dalam skala besar.
Menurut Ruth (2001) dalam Firman (2018:274), terdapat empat tipe wirausaha perempuan yaitu:

1. Semuanya berkompeten pada mimpi kewirausahaan dan pemikiran konvensional tentang peran gender. Mereka cenderung terlibat dalam aktivitas yang biasa disebut "pekerja wanita" yang terpaksa untuk berbisnis karena kebutuhan ekonomi.

2. Wirausaha lokal menunjukan sedikit minat pada cita-cita kewirausahaan dengan berpegangan pada opini konvensional tentang para gender. Mereka terlibat dalam aktivitas yang biasanya disebut dengan "pekerja wanita" yang bertujuan untuk mencari pangakuan diri dan ekspresi personal.

3. Inovator adalah wanita professional yang berpegang teguh pada cita-cita kewirausahaan dalam pencapaian dari melalui kesuksesan dalam berbisnis.

4. Wirausaha radikal tidak berpegang secara teguh dalam cita-cita kewirausahaan atau percaya pada gender konvensional. Wanita secara umum menyatakan dirinya sebagai bagian dari pergerakan kewanitaan dan mereka berbisnis untuk meningkatkan derajat wanita di masyarakat.

Dalam menjalankan usahanya, Munfaqiroh (2018:60) menyatakan bahwa wirausaha perempuan tidak jarang menghadapi kendala yang meliputi terlalu banyak pikiran, empati berlebihan, manajemen bisnis, takut gagal, dan sering ketakutan untuk mengambil risiko besar dalam memulai bisnis dan mengambil langkah untuk mengembangkan usahanya.

\section{Bisnis Online}

Menurut Kenrianto (2016:30) dalam Firman (2018:275), bisnis online adalah bisnis yang dijalankan dengan internet. 
Ada beberapa hal yang harus diketahui mengenai bisnis online yaitu:

1. Pelanggan datang ke website atau kios online anda.

2. Iklan anda dipasang di internet.

3. Semakin banyak orang ke website atau kios online anda, semakin banyak calon pembeli anda.

4. Jika memiliki website sendiri anda membayar sewa web hosting dan domain.

5. Bisa dikerjakan sedikit orang.

\section{Faktor-Faktor yang Mempengaruhi Perempuan Berwirausaha Online}

Keputusan perempuan untuk berwirausaha dapat dipengaruhi oleh berbagai alasan. Penelitian Primadhita (2018:169) menemukan bahwa faktor internal dan faktor eksternal berpengaruh signifikan terhadap keputusan perempuan berwirausaha. Penelitian ini mencakup 100 responden wirausaha perempuan di Cilandak, Jakarta Selatan. Faktor internal yang diteliti mencakup keyakinan diri, keahlian, dan motivasi diri. Sementara, faktor eksternal meliputi lingkungan keluarga, lingkungan sosial, dan risiko. Diketahui faktor eksternal memiliki pengaruh yang lebih dominan yaitu 0,545 dibandingkan dengan faktor internal sebesar 0,443. Besarnya kemampuan faktor internal dan faktor eksternal dalam menjelaskan keputusan perempuan berwirausaha sebesar 67,9\%, sedangkan sisanya sebesar 32,1\% dapat dijelaskan oleh variabel lain yang tidak digunakan dalam penelitian ini.

Penelitian Munfaqiroh (2018:38) menemukan faktor modal, kemandirian, dan faktor keluarga berpengaruh signifikan terhadap keputusan perempuan berwirausaha, baik secara parsial maupun secara simultan. Penelitian mencakup 70 wirausaha perempuan yang tergabung dalam UMKM Posdaya, Malang. Faktor modal memiliki pengaruh yang paling dominan yaitu sebesar 0,522, sementara kemandirian berpengaruh sebesar 0,210 dan faktor keluarga berpengaruh 0,256. Modal ini dapat diperoleh dengan dana milik sendiri atau modal pinjaman. Penelitian menemukan bahwa dalam memulai usaha wanita terkadang lebih cenderung menggunakan modal milik sendiri agar tidak mempunyai tanggungan untuk mengembalikannya. Variabel faktor modal, kemandirian, dan faktor keluarga dapat menjelaskan variabel keputusan perempuan berwirausaha sebesar $69 \%$ dan $31 \%$ sisanya dapat dijelaskan oleh variabel lain yang tidak digunakan dalam penelitian.

Sementara itu, penelitian Firman (2018:280) menemukan bahwa keberhasilan diri, toleransi risiko, dan kebebasan bekerja berpengaruh signifikan terhadap keinginan perempuan berwirausaha online. Koefisien regresi keberhasilan diri sebesar 0,390, sementara toleransi akan risiko sebesar 0,245, dan kebebasan dalam bekerja sebesar 0,271. Faktor keberhasilan diri berpengaruh lebih besar dibandingkan faktor toleransi risiko dan kebebasan bekerja. Dalam hal ini, keberhasilan diri yaitu keberhasilan berwirausaha sebagai pendorong keinginan seseorang untuk menjadi wirausaha yang diidentikkan dengan persepsi keberhasilan sebagai hasil yang menguntungkan atau berharap untuk berakhir melalui pencapaian tujuan dari usahanya. Penelitian ini mencakup perempuan wirausaha yang terdaftar pada Badan Pemberdayaan Perempuan dan Perlindungan Anak Pemerintah Kota Makassar berjumlah 32 orang.

\section{Kerangka Penelitian}

Dari uraian di atas, maka dugaan sementara yang dapat diambil adalah: 
1. H1: lingkungan keluarga berpengaruh signifikan terhadap motivasi perempuan berwirausaha online di Jakarta.

2. H2: modal berpengaruh signifikan terhadap motivasi perempuan berwirausaha online di Jakarta.

3. H3: kebebasan bekerja berpengaruh signifikan terhadap motivasi perempuan berwirausaha online di Jakarta.

Berdasarkan ketiga hipotesis di atas, dapat disusun kerangka penelitian sebagai berikut:

Gambar 1

Kerangka Penelitian

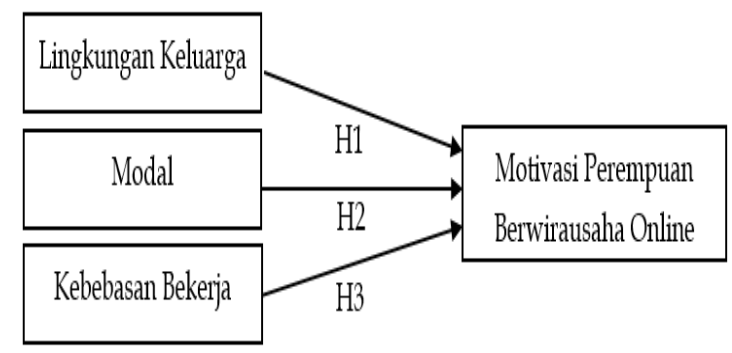

Sumber: konsep penelitian penulis, 2019

\section{METODE PENELITIAN Sampel Penelitian}

Penelitian ini mencakup perempuan yang memiliki usaha online di wilayah Jakarta. Pengambilan sampel terdiri atas 80 responden dengan menggunakan teknik non-probability sampling. Teknik nonprobability sampling yaitu semua elemen dalam populasi tidak memiliki kesempatan yang sama untuk dipilih menjadi sampel. Hal ini dilakukan karena adanya keterbatasan waktu penelitian (Primadhita, 2018: 164). Data yang digunakan berasal dari jawaban kuisioner yang telah diisi oleh responden. Data primer yang dihasilkan dari kuisioner tersebut kemudian diolah dan dianalisis dengan program SPSS untuk melihat pengaruh variabel lingkungan keluarga, modal, dan kebebasan bekerja terhadap variabel motivasi perempuan berwirausaha online.

\section{Operasionalisasi Variabel}

Variabel yang digunakan dalam penelitian ini meliputi lingkungan keluarga, modal, dan kebebasan bekerja sebagai variabel independen, sedangkan variabel dependen yang digunakan adalah motivasi perempuan berwirausaha online. Rincian Variabel independen dan dependen yang dipakai dalam penelitian adalah sebagai berikut:

Tabel 1

Operasionalisasi Variabel

\begin{tabular}{|c|c|c|}
\hline Variabel dan Definisi & Indikator & Referensi \\
\hline $\begin{array}{l}\text { Lingkungan Keluarga }\left(X_{1}\right) \\
\text { - Faktor penentu yang } \\
\text { bersumber dari latar } \\
\text { belakang keluarga }\end{array}$ & $\begin{array}{l}\text { 1. Berasal dari keluarga } \\
\text { wirausaha } \\
\text { 2. Keluarga mendukung } \\
\text { untuk berwirausaha } \\
\text { 3. Keluarga membutuhkan } \\
\text { tambahan penghasilan }\end{array}$ & $\begin{array}{l}\text { Munfaqiroh (2018), } \\
\text { Primadhita (2018) }\end{array}$ \\
\hline $\begin{array}{l}\text { Modal }\left(X_{2}\right) \\
\text { - Kemudahan dan } \\
\text { ketersediaan modal usaha }\end{array}$ & $\begin{array}{l}\text { 1. Usaha memerlukan modal } \\
\text { yang tidak besar } \\
\text { 2. Modal berasal dari dana } \\
\text { sendiri } \\
\text { 3. Kemudahan memperoleh } \\
\text { akses modal atau pinjaman }\end{array}$ & Munfaqiroh (2018) \\
\hline $\begin{array}{l}\text { Kebebasan Bekerja }\left(X_{3}\right) \\
\text { - Keinginan untuk bekerja } \\
\text { namun tidak terikat waktu } \\
\text { dan tempat. }\end{array}$ & $\begin{array}{l}\text { 1. Waktu kerja fleksibel. } \\
\text { 2. Dapat dilakukan di } \\
\text { rumah (usaha rumahan). } \\
\text { 3. Bekerja secara mandiri }\end{array}$ & Firman (2018) \\
\hline $\begin{array}{l}\text { Motivasi Perempuan } \\
\text { Berwirausaha Online (Y) } \\
\text { - Menentukan pilihan dan } \\
\text { mengambil tindakan untuk } \\
\text { mulai menjalankan usaha } \\
\text { secara online. }\end{array}$ & $\begin{array}{l}\text { 1. Ketertarikan untuk } \\
\text { berwirausaha online } \\
\text { 2. Kemauan menjalankan } \\
\text { usaha online } \\
\text { 3. Kesenangan menjalankan } \\
\text { usaha online }\end{array}$ & $\begin{array}{l}\text { Primadhita (2018) } \\
\text { Firman (2018) }\end{array}$ \\
\hline
\end{tabular}

\section{Metode Analisis Data}

Penelitian ini diawali dengan pengumpulan data primer yang berasal dari kuisioner yang telah diisi oleh responden. Pengisian kuisioner dilakukan dengan menjawab penyataan yang telah 
disusun dengan menggunakan teknik skala likert yang menggolongkan jawaban ke dalam lima skala yaitu sangat tidak setuju, tidak setuju, netral, setuju, dan sangat setuju. Kumpulan data primer yang berasal dari kuisioner kemudian diolah dengan program SPSS (Statistical Package for Social Science). Pada awal pengujian, dilakukan uji reliabilitas dan uji validitas. Hasil kuisioner dinyatakan reliable jika jawaban pertanyaan konsisten dari waktu ke waktu, dengan nilai Cronbach Alpha (a) $>0,6$ untuk setiap variabel. Sementara itu, data dikatakan valid jika indikator penelitian memiliki korelasi antara skor masing-masing indikator terhadap skor totalnya (Sugiyono, 2007).

Selanjutnya, dilakukan uji asumsi klasik berupa uji multikolineritas, uji heteroskedastis, dan uji normalitas. Uji multikolinearitas bertujuan untuk mengetahui korelasi antar variabel bebas, uji heteroskedastis bertujuan untuk mengetahui apakah varians berubah dari observasi ke observasi, dan uji normalitas bertujuan untuk mengetahui apakah variabel yang digunakan terdistribusi normal atau mendekati normal. Penelitian ini tidak melakukan uji autokorelasi karena data yang digunakan adalah data kuisioner, dimana data diukur pada saat bersamaan atau dalam satu periode waktu (Ariefianto, 2012).

Analisis regresi linier berganda merupakan tahap terakhir dari pengolahan data dalam penelitian ini, dimana dilakukan untuk melihat pengaruh variabel-variabel bebas terhadap variabel terikat. Analisis dilakukan berdasarkan hasil adjusted R2, serta nilai statistik pada uji $F$ dan uji t. Uji F digunakan untuk mengetahui tingkat siginifikansi pengaruh variabel bebas secara simultan terhadap variabel terikat. Sedangkan uji t digunakan untuk mengetahui seberapa jauh pengaruh satu variabel bebas secara individual dapat menerangkan variasi variabel terikat. Nilai koefisien determinasi (R2) dan adjusted R2 digunakan untuk mengukur seberapa jauh kemampuan sebuah model menerangkan variasi variabel terikat. Penambahan variabel bebas akan otomatis meningkatkan nilai R2, tidak peduli apakah variabel bebas tersebut berpengaruh signifikan terhadap variabel terikat atau tidak. Hal ini dapat menyebabkan model menjadi bias. Oleh karenanya, penelitian akan menggunakan nilai adjusted R2 untuk menghindari model menjadi bias dalam menerangkan variasi variabel dependen. Nilai adjusted R2 dapat naik atau turun ketika satu variabel bebas ditambahkan kedalam model (Ariefianto, 2012).

Adapun model regresi berganda dalam penelitian ini adalah sebagai berikut:

$$
Y=\beta 0+\beta 1 X 1+\beta 2 X 2+\beta 3 X 3
$$

Dimana:

$$
\begin{aligned}
& \text { - } \mathrm{Y}=\text { Motivasi perempuan } \\
& \text { berwirausaha online } \\
& \text { - } \beta 0=\text { Konstanta } \\
& \text { - } \quad \beta 1, \beta 2, \beta 3=\text { Koefisien regresi } \\
& \text { - } \mathrm{X} 1=\text { Lingkungan keluarga } \\
& \text { - } \mathrm{X} 2=\text { Modal } \\
& \text { - } \mathrm{X} 3=\text { Kebebasan Bekerja }
\end{aligned}
$$

\section{HASIL PENELITIAN DAN PEMBAHASAN Uji Validitas dan Reliabilitas}

Nilai corected item-total correlation untuk semua butir pernyataan pada setiap variabel lebih besar dari 0,2 dan nilai alphacronbach untuk setiap variabel lebih besar dari 0,6. Hal ini menunjukkan bahwa masing-masing indikator pada variabel lingkungan keluarga, modal, kebebasan bekerja, dan motivasi perempuan berwirausaha online secara keseluruhan telah valid dan reliabel sehingga dapat digunakan dalam penelitian. 


\section{Pengujian Asumsi Klasik}

Hasil pengujian asumsi klasik menyatakan bahwa tidak terjadi pelanggaran asumsi klasik. Pengujian asumsi heteroskedastisitas dilakukan dengan Uji Spearman. Hasil menunjukan tidak adanya heteroskedastisitas karena nilai signifikansi yang diperoleh lebih besar dari 0,05. Pada pengujian asumsi multikolinearitas, diketahui nilai VIF variabel X1, X2 dan X3 kurang dari 10, sehingga tidak terjadi pelanggaran asumsi multikolinearitas. Selanjutnya, pengujian asumsi normalitas dilakukan dengan Uji Kolmogorov-Smirnov. Hasil menunjukkan data yang digunakan berdistribusi normal dengan nilai signifikansi lebih besar dari 0,05 .

\section{Uji Kelayakan Model}

Besarnya kemampuan variabel bebas yang meliputi lingkungan keluarga (LK), modal (M), dan kebebasan bekerja (KB) dalam menjelaskan variabel terikat motivasi perempuan berwirausaha online (MWO) sebesar 0,531 atau 53,1\% sedangkan sisanya sebesar 0,469 atau $46,9 \%$ dijelaskan oleh variabel lain yang tidak digunakan dalam penelitian ini.

Tabel 2

Model Summary

\begin{tabular}{|l|r|r|r|r|r|}
\multicolumn{7}{|c|}{ Model Summary } \\
\hline Model & R & R Square & $\begin{array}{c}\text { Adjusted R } \\
\text { Square }\end{array}$ & $\begin{array}{c}\text { Std. Error of the } \\
\text { Estimate }\end{array}$ & Durbin-Watson \\
\hline 1 & .7413 & .549 & .531 & 1.26061 & 2.189 \\
\hline
\end{tabular}

a. Predictors: (Constant), LK, M, KB

b. Dependent Variable: MWO

Sumber: output SPSS data diolah, 2019

Adapun uji-F dilakukan dengan hipotesis sebagai berikut:

Ho : tidak terdapat pengaruh lingkungan keluarga, modal, dan kebebasan bekerja terhadap motivasi perempuan berwirausaha online.
Ha : terdapat pengaruh lingkungan keluarga, modal, dan kebebasan bekerja terhadap motivasi perempuan berwirausaha online.

Hasil penelitian menunjukkan bahwa nilai probabilitas $\mathrm{F}$ hitung sebesar Sig $\mathrm{F}=$ 0.000, sehingga Ho ditolak atau $\mathrm{Ha}$ diterima, yang berarti terdapat pengaruh yang signifikan antara lingkungan keluarga, modal, dan kebebasan bekerja terhadap motivasi perempuan berwirausaha online. Penelitian menghasilkan model persamaan regresi linier ganda $Y=0,918+0,249 X 1+0,325 X 2$ $+0,343 X 3$ yang menunjukkan pengaruh lingkungan keluarga, modal, dan kebebasan bekerja terhadap motivasi perempuan berwirausaha online.

Tabel 3

Anova

\begin{tabular}{|c|c|c|c|c|c|c|}
\hline \multicolumn{7}{|c|}{ ANOVAb } \\
\hline Moc & & Sum of Squares & $D f$ & Mean Square & $\mathrm{F}$ & Sig. \\
\hline \multirow[t]{3}{*}{1} & Regression & 147.114 & 3 & 49.038 & 30.858 & $.000^{2}$ \\
\hline & Residual & 120.774 & 76 & 1.589 & & \\
\hline & Total & 267.888 & 79 & & & \\
\hline \multicolumn{7}{|c|}{ a. Predictors: (Constant), KB, LK, M } \\
\hline \multicolumn{7}{|c|}{ b. Dependent Variable: MWO } \\
\hline \multicolumn{7}{|c|}{ Sumber: ouput SPSS data diolah, 2019} \\
\hline
\end{tabular}

\section{Uji Hipotesis}

Hasil pengujian hipotesis parsial didasarkan pada tabel berikut:

Tabel 4

Coefficients

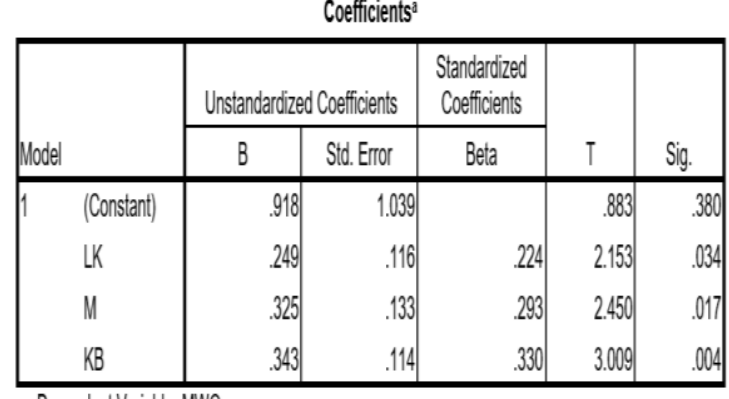

a. Dependent Variable: MWO

Sumber: output SPSS ditat dioldh, 2019 
Pengujian Hipotesis Pengaruh Lingkungan Keluarga terhadap Motivasi Perempuan Berwirausaha Online (H1)

Hipotesis pertama dalam penelitian ini adalah terdapat pengaruh yang signifikan antara lingkungan keluarga terhadap motivasi perempuan berwirausaha online sebagai berikut:

H1o: tidak terdapat pengaruh lingkungan keluarga terhadap motivasi perempuan berwirausaha online.

H1a: terdapat pengaruh lingkungan keluarga terhadap motivasi perempuan berwirausaha online.

Nilai probabilitas t-hitung variabel lingkungan keluarga adalah sebesar 0,034. Sehingga H1o ditolak atau H1a diterima, yang berarti terdapat pengaruh yang signifikan antara lingkungan keluarga terhadap motivasi perempuan berwirausaha online.

\section{Pengujian Hipotesis Pengaruh Modal terhadap Motivasi Perempuan Berwirausaha Online (H2)}

Hipotesis kedua dalam penelitian ini adalah terdapat pengaruh yang signifikan antara modal terhadap motivasi perempuan berwirausaha online sebagai berikut:

H2o: tidak terdapat pengaruh modal terhadap motivasi perempuan berwirausaha online.

$\mathrm{H} 2 \mathrm{a}$ : terdapat pengaruh modal terhadap motivasi perempuan berwirausaha online.

Nilai probabilitas t-hitung variabel modal adalah sebesar 0,017 . Sehingga $\mathrm{H} 2 \mathrm{o}$ ditolak atau H2a diterima, yang berarti terdapat pengaruh yang signifikan antara modal terhadap motivasi perempuan berwirausaha online.
Pengujian Hipotesis Pengaruh Kebebasan Bekerja terhadap Motivasi Perempuan Berwirausaha Online (H3)

Hipotesis ketiga dalam penelitian ini adalah terdapat pengaruh yang signifikan antara kebebasan kerja terhadap motivasi perempuan berwirausaha online sebagai berikut:

H3o: tidak terdapat pengaruh kebebasan kerja terhadap motivasi perempuan berwirausaha online.

H3a: terdapat pengaruh kebebasan kerja terhadap motivasi perempuan berwirausaha online.

Nilai probabilitas t-hitung variabel kebebasan bekerja adalah sebesar 0,004. Sehingga H3o ditolak atau H3a diterima, yang berarti terdapat pengaruh yang signifikan antara kebebasan kerja terhadap motivasi perempuan berwirausaha online.

\section{Pembahasan}

Berdasarkan hasil penelitian, diketahui signifikansi p-value lebih kecil dari 0,05 di semua variabel independen. Dengan demikian dapat diperoleh model persamaan regresi linier ganda $Y=0,918+$ $0,249 \times 1+0,325 X 2+0,343 X 3$.

\section{Pengaruh Lingkungan Keluarga terhadap Motivasi Perempuan Berwirausaha Online}

Motivasi perempuan berwirausaha online dipengaruhi oleh faktor lingkungan keluarga dengan arah positif sebesar 0,249. Semakin besar faktor pendukung yang berasal dari lingkungan keluarga berupa keluarga wirausaha, dukungan keluarga, dan kebutuhan tambahan penghasilan, maka semakin besar motivasi perempuan berwirausaha online.

Hal ini sejalan dengan hasil penelitian Yuridistya (2018) dan Munfaqiroh (2018) yang menyatakan bahwa lingkungan keluarga berpengaruh positif dan signifikan terhadap motivasi perempuan 
berwirausaha. Motivasi perempuan memutuskan berwirausaha online akan semakin besar manakala perempuan tersebut memiliki orang tua atau anggota keluarga lain yang berprofesi sebagai wirausaha. Dukungan keluarga dan jiwa kewirausahaan yang ditimbulkan oleh keluarga akan menambah motivasi perempuan untuk memulai dan menjalankan bisnis. Tidak hanya itu, kebutuhan ekonomi keluarga untuk mendapatkan tambahan penghasilan juga menjadi faktor penting yang mempengaruhi perempuan untuk berwirausaha online.

\section{Pengaruh Modal terhadap Motivasi Perempuan Berwirausaha Online}

Modal menjadi faktor penentu dan berpengaruh signifikan terhadap motivasi perempuan berwirausaha online. Hal ini sesuai dengan penelitian yang dilakukan oleh Munfaqiroh (2018). Pada saat perempuan memulai usaha baru, kebutuhan modal menjadi salah satu pertimbangan. Wirausaha online dipilih oleh perempuan sebagai sumber usaha dan tambahan penghasilan karena kecenderungannya yang tidak memerlukan modal awal yang besar. Pada dasarnya, perempuan lebih menyukai jika menggunakan dana sendiri untuk memulai usaha ketimbang pinjaman karena tidak harus memikirkan beban tanggungan untuk membayar pinjaman tersebut. Namun manakala dana sendiri dirasa tidak mencukupi, mereka mencari modal dengan meminjam kepada pihak lain untuk kepentingan usahanya. Dalam hal ini, perempuan yang berwirausaha harus dibekali pula dengan pengetahuan mengenai manajemen pengelolaan keuangan yang benar dalam menjalankan bisnis agar aliran dana keluar masuk dapat termonitor dengan baik. Ketika usaha mulai berjalan dan kemudian berkembang, kebutuhan akan modal juga akan bertambah. Oleh karena itu, akses permodalan juga sangat dibutuhkan perempuan untuk bisa mengembangkan bisnisnya agar menjadi semakin besar. Akses terhadap pembiayaan UMKM misalnya dapat berasal dari bantuan pemerintah, subsidi, dan pinjaman bank atau lembaga keuangan lain.

\section{Pengaruh Kebebasan Bekerja terhadap Motivasi Perempuan Berwirausaha Online}

Motivasi perempuan untuk berwirausaha online salah satunya juga dipengaruhi oleh keinginan untuk memiliki pekerjaan dan tambahan penghasilan dengan pekerjaan yang tidak terikat, baik itu terkait dengan waktu kerja yang fleksibel, usaha yang bisa dikerjakan di rumah atau di lokasi yang dekat dengan rumah, dan pekerjaan yang bisa dilakukan secara mandiri. Semakin tinggi keinginan untuk memiliki kebebasan dalam bekerja, maka akan semakin besar motivasi perempuan untuk berwirausaha online. Hal ini sejalan dengan penelitian yang dihasilkan oleh Firman (2018). Dengan berwirausaha online, perempuan akan cenderung dapat menyusun jadwal bekerja dengan lebih fleksibel sesuai dengan kebutuhannya. Dengan demikian, perempuan dapat lebih mudah mengatur peran gandanya baik itu sebagai pelaku usaha di ranah publik dan sebagai ibu rumah tangga di ranah domestik.

\section{KESIMPULAN}

Berdasarkan hasil penelitian, dapat disimpulkan hal-hal sebagai berikut:

1. Faktor lingkungan keluarga berpengaruh positif terhadap motivasi perempuan berwirausaha online di Jakarta. 
2. Faktor modal berpengaruh positif terhadap motivasi perempuan berwirausaha online di Jakarta.

3. Faktor kebebasan bekerja berpengaruh positif terhadap motivasi perempuan berwirausaha online di Jakarta.

\section{SARAN}

Berdasarkan simpulan di atas, saran yang dapat diberikan adalah:

1. Penelitian ini hanya mencakup tiga variabel independen yaitu lingkungan keluarga, modal, dan kebebasan bekerja dalam menganalisis pengaruhnya terhadap motivasi perempuan berwirausaha online. Faktor lain seperti jenis usaha, kemudahan membuat toko online, kondisi permintaan dan tren pasar, dan kemudahan bergabung dengan layanan pasar online belum tercakup di dalam penelitian. Untuk itu, penelitian selanjutnya diharapkan dapat memasukkan faktor-faktor tersebut.

2. Penelitian tidak dapat digeneralisasi kesimpulannya untuk wilayah yang berbeda. Penelitian lain yang sama dengan penelitian ini pada wilayah yang berbeda dapat menghasilkan kesimpulan yang berbeda. Untuk memperkaya hasil penelitian, diharapkan penelitian selanjutnya mengambil wilayah penelitian lain.

\section{DAFTAR PUSTAKA}

Ariefianto, M. Doddy. 2012. Ekonometrika: Esensi dan Aplikasi dengan Menggunakan Eviews. Jakarta: Penerbit Erlangga.

Firman, Ahmad. 2018. Faktor-Faktor yang Memotivasi Wanita Berwirausaha Online di Kota Makassar. Jurnal IImiah Bisnis dan Kewirausahaan, Vol. 7 No. 3: 271-282.

Munfaqiroh, Siti. 2018. Analisis Keputusan Wanita dalam Berwirausaha. Jurnal Administrasi dan Bisnis, Vol. 12 No. 1: 32-39.

Pambudy, Rachmat. 2017. Kewirausahaan dan Manajemen Bisnis Kecil. Bogor: Idemedia Pustaka Utama.

Primadhita, Yuridistya, dkk. 2018. Pengaruh Faktor Internal dan Faktor Eksternal terhadap Keputusan Perempuan Berwirausaha. Jurnal Pengembangan Wiraswasta, Vol. 20 No. 03: 161-170.

Sugiyono. 2007. Statistika untuk Penelitian. Bandung: CV Alfabeta.

United Nation Development Programs (UNDP). $2018 . \quad$ Women's Entrepreneurship and Access to Finance: Challenges and Opprotunities of Women-led Social Enterprises in Indonesia. Indonesia: UNDP. 